\title{
Molecular identification of Ditylenchus destructor nematode with PCR Species-Specific primers in the Moscow region
}

\author{
Niloufar Mahmoudi ${ }^{1,2 *}$, Yousef Naserzadeh ${ }^{1,2}$, Elena N. Pakina ${ }^{1}$, \\ Liudmila A. Limantceva ${ }^{2}$, Davoud K. Nejad ${ }^{3}$ \\ ${ }^{1}$ Peoples' Friendship University of Russia (RUDN University), \\ Moscow, Russian Federation \\ ${ }^{2}$ Russian Plant Quarantine Center (VNIIKR), \\ Moscow region, Russian Federation \\ ${ }^{3}$ Semnan University, Semnan, Iran \\ *Corresponding author: niloofarmahmoodi@ymail.com
}

\begin{abstract}
Potato (Solanum tuberosum L.) is one of the most vital food and industrial crop and Ditylenchus destructor is an influential pathogenic potato nematode and is quarantine pest in many states and territories. As a result, the polymerase chain reaction (PCR) protocol was optimized to identify Ditylenchus destructor reliably and rapidly. The species-specific internal transcribed spacer (ITS) was used as the primer of the $D$. destructor ribosomal DNA gene. Some populations of this species from the Moscow region in the Russian Federation were investigated through species-specific primer PCR. New sequence from ITS-rRNA was deposited in the GenBank under accession number MN122076. The current molecular technique is more appropriate to distinguishing of nematode species, since it is practical, fast and precise.
\end{abstract}

Key words: Potato, diagnosis, Ditylenchus destructor, PCR Species-Specific, nematode, ITS

\section{ACKNOWLEDGMENTS}

The research has been conducted with the support of the «RUDN University Program 5-100».

\section{Article history:}

Received: 5 September 2019. Accepted: 29 November 2019

\section{For citation:}

Mahmoudi N, Naserzadeh Y, Pakina E, Limantceva L, Nejad DK. Molecular identification of Ditylenchus destructor nematode with PCR Species-Specific primers in the Moscow region. RUDN Journal of Agronomy and Animal Industries. 2019; 14(4):430 - 436. doi: 10.22363/2312-797X-201914-4-430-436

(c) Mahmoudi N., Naserzadeh Y., Pakina E.N., Limantceva L.A., Nejad D.K., 2019.

(i) This work is licensed under a Creative Commons Attribution 4.0 International License https://creativecommons.org/licenses/by/4.0/ 


\section{Introduction}

Potato is assaulted by several nematodes, belonging to different species which can sustain and duplicate on tubers causing immediate and circuitous misfortunes [1]. Major nematode species of potato include Globodera spp., Meloidogyne spp., Nacobbus aberrans, Ditylenchus spp, and Pratylenchus spp. [2]. Several other nematodes species are also associated with potato, however, their monetary significance has not been appropriately evaluated [2]. Some nematode species recently viewed as non-harming to crops are ceaselessly announced as a risk to trim creation because of the impact of environmental change [3] and fluctuating trimming designs [4]. The genus Ditylenchus (Nematoda: Anguinidae) involves numerous cosmopolitan species and is known to have the most stretched out effect on agriculture [5]. Ditylenchus destructor is regularly alluded to as the potato tuber decay nematode, which is far-reaching and significant in cool and sticky situations [6,7]. As per (EPPO, 2007) [8], potato rot nematode is accounted for to be available in over $70 \%$ of the part nations of the association in the European domains. Potato decay nematode may spread by the material planted as well as utilizing water system water. It has been demonstrated that it has general inclination to cause harm in colder and increasingly damp territories (EPPO/CABI,1997) [9]. On the other hand, the general isolate guidelines against the potato decay nematode in European regions have been nullified, as it was expelled from EPPO quarantine list in 1984, due to its extremely wide circulation in the area (EPPO, 1987, 1988) [9]. Thusly, there is an expanding request by nematode taxonomists to survey these nematodes with various points. One of the points is to grow new apparatuses for agronomic administration and to address the isolate guidelines prerequisites [10,11]. Exact recognizable proof of $D$. destructor is significant for the screening of plant germplasm to reproduce and improvement of safe cultivars. Rather than morphometric information, nematode ID utilizing various molecular apparatuses gives precise and quick personality of species under examinations. The European and Mediterranean Plant Protection Organization (EPPO) offers an analytic convention for D. destructor (EPPO, 2008). The current method recommended by the EPPO for diagnosis of $D$. destructor was developed by Marek et al. [12]. Aim of the present study was to use a fast and affordable PCR-based diagnostic method capable of the unambiguous identification of $D$. destructor.

\section{Materials and methods}

DNA extraction. Nematodes were extracted from potatoes (Solanum tuberosum L.) collected in Russia, Moscow region. Several nematode specimens from the population were put into a drop of water and cut by a scalpel under a camera-equipped ZEISS Axioskop50 ${ }^{\circledR}$ microscope. DNA extraction from the material in this research was laid out by treating the specimens with Proteinase $\mathrm{K}$ that was followed by removing proteins with no extraction with organic solvents. For this purpose, a DNA-Ekstran-2 set No EX-511-100 (Synthol, Moscow) was used.

PCR with species-specific primer. The species-specific PCR reaction was performed with samples (final volume $25 \mu \mathrm{l}$ ), containing $5 \mu \mathrm{l}$ of $10 \mathrm{X}$ reaction buffer, $0.6 \mu \mathrm{l}$ of each primer (DIT des R, DIT uni F), $13.8 \mu 1$ sterile distilled water and $5 \mu 1$ DNA. Amplification conditions for the reaction were as follows: denaturation for 3 minutes at $95{ }^{\circ} \mathrm{C}$; 35 cycles at $95^{\circ} \mathrm{C}$ for 30 seconds, $64^{\circ} \mathrm{C}$ for 30 seconds and $72{ }^{\circ} \mathrm{C}$ for 30 seconds; a final extension at $72^{\circ} \mathrm{C}$ for $5 \mathrm{~min}$. 
Sequence analysis. Sequencing was done by the generally accepted protocol with the use of Genetic Analyzer AB-3500 (Applied Biosystems, USA). Primary comparison for the results of the sequence with the GeneBank genetic sequence database was performed by the NCBI BLAST web site (http://www.ncbi.nlm.nih.gov/BLAST). BioEdit v.7.0.5.3, sequence alignment editor was used for sequence checking, alignment, and editing. Pairwise genetic distances between the sequences were recognized by Kimora's two-parameter model. The new sequence obtained in the present study was submitted to the GenBank database under the accession numbers MN122076.

\section{Results and discussion}

Identification of plant parasites that adversely influence agro financial matters is a significant issue for compelling yield insurance. Specifically compelling are those pests that ought to be dispensed with or contained attributable to their isolate status, which forces a flat out lawful commitment in the European Union to restrict and eradicate plants infested with such pests. In this research, we built up the species-specific primer for indication of Ditylenchus destructor (Fig. 2). The primers were tested with samples from the Moscow region. PCR with species-specific primer was produced for separation of D. dipsaci and D. gigas utilizing species-specific SCAR or ITS-rRNA primers [1215]. The results of the present investigation demonstrate extraidentification of $D$. destructor from different types of this genus by a PCR species-specific method. To improve interpretation of results, high-resolution agarose gels can be utilized during electrophoresis. Given the lengths of the $D$. destructor ITS1 sequences change significantly, seven haplotypes exist; the main accessible strategies that possibly can separate among the haplotypes are those of Subbotin et al. (2005) [14, 16] and Liu et al. (2007) $[17,18]$. Respect to the explicitness, affectability, and speed, the portrayed indicative conventions can be utilized for discovery purposes by phytosanitary diagnosticians to limit the spread of destructive Ditylenchus species during fare and import of plants and plant items. On account of the wide host scope of Ditylenchus, the utilization of species-specific PCR indication ought to quicken screening for it during the exchange.

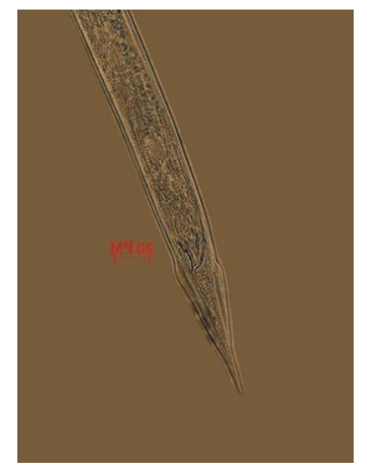

$A$

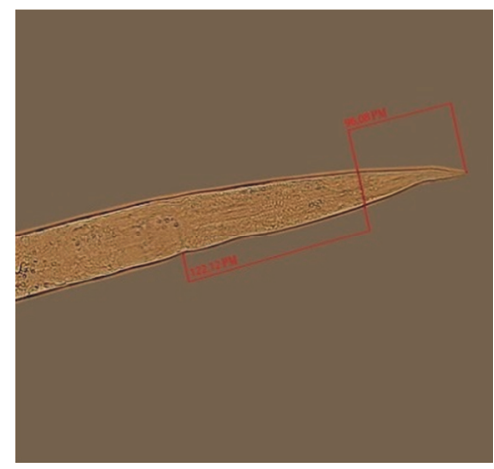

$B$

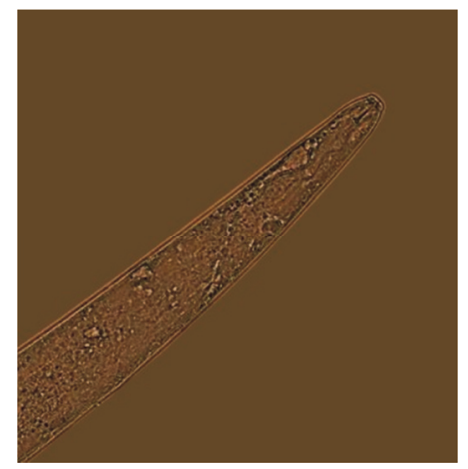

C

Fig. 1. Micrographs of diagnosing characteristics for nematodes found in potato tubers: A -Male bursa and tail; B - female vulva, Anus and tail; C - head and stylet 


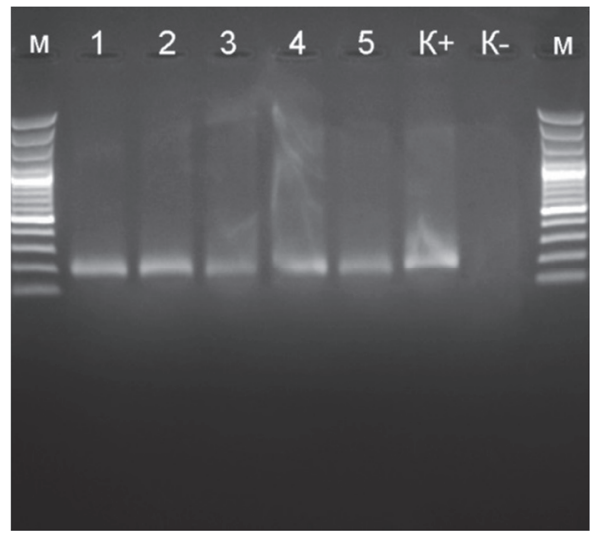

Fig. 2. Gel with amplification products obtained in PCR with species-specific primer. Lanes: $\mathrm{M}=100$ bp DNA ladder (Promega); K- = control without DNA

\section{Conclusions}

In summary, the analysis of ITS-rRNA gene from several destructor samples collected in the Moscow region with species-specific PCR primer allowed us to confirm their species identification and suggest the effective and rapid distinguishing technique. These results will be especially important for accurate detection of Ditylenchus spp. which will have implications in the development of resistant cultivars. Although the comparison of the sequence obtained from this study with Genbank has shown 98 percent similarity with species $D$. destructor in the world that is a good indicator for our identity.

\section{References}

1. López M, Riegel R, Lizana C, Behn A. Identification of virus and nematode resistance genes in the Chilota Potato Genebank of the Universidad Austral de Chile. Chilean journal of agricultural research. 2015; 75(3):320 -327. doi: 10.4067/S0718-58392015000400008

2. Scurrah MI, Niere B, Bridge J. Nematode parasites of solanum and sweet potatoes. In: Luc M, Sikora RA, Bridge J. (eds.) Plant parasitic nematodes in subtropical and tropical agriculture. 2nd ed. Wallingford, UK: CABI Publishing; 2005. p. 193 - 219. doi: 10.1079/9780851997278.0193

3. Hijmans RJ. The effect of climate change on global potato production. American journal of potato research. 2003; 80(4):271-279. doi: 10.1007/BF02855363

4. Nicol JM, Turner SJ, Coyne DL, Den Nijs L, Hockland S, Maafi ZT. Current nematode threats to world agriculture. In: Jones J, Gheysen G, Fenoll C. (eds.) Genomics and molecular genetics of plant-nematode interactions. Dordrecht: Springer; 2011. p. 21—43. doi: 10.1007/978-94-0070434-3_2

5. Fortuner R. On the genus Dilylenchus Filipjev, 1936 (Nernatoda: Tylenchida). Revue Nematol. 1982; 5(1):17-38.

6. Thorne G. Ditylenchus destructor n. sp. the potato rot nematode, and Ditylenchus dipsaci (Kühn, 1857) Filipjev, 1936, the teasel nematode (Nematoda: Tylenchidae). Proceedings of the helminthological Society of Washington. 1945; 12(2):27-34.

7. Plowright RA, Caubel G, Mizen KA. Plant resistance to parasitic nematodes. In: Starr JL, Cook R, Bridge J. (eds.) Ditylenchus species. Wallingford, UK: CABI Publishing; 2002. p. 107139. doi: $10.1079 / 9780851994666.0107$

8. Hodda M, Nobbs J. A review of current knowledge on particular taxonomic features of the Australasian nematode fauna, with special emphasis on plant feeders. Australasian Plant Pathology. 2008; 37(3):308-317. doi: 10.1071/AP08024 
9. Kruus E. Impact of trade on distribution of potato rot nematode (Ditylenchus destructor) and other plant nematodes. Agronomy Research. 2012; 10(1-2):319-328.

10. Powers TJARP. Nematode molecular diagnostics: from bands to barcodes. Annu Rev Phytopathol. 2004; 42:367-383. doi: 10.1146/annurev.phyto.42.040803.140348

11. Naserzadeh Y, Kartoolinejad D, Mahmoudi N, Zargar M, Pakina E, Heydari M, Astarkhanova T, Kavhiza NJ. Nine strains of Pseudomonas fluorescens and P. putida: Effects on growth indices, seed and yield production of Carthamus tinctorius L. Research on Crops. 2018; 19(4):622 632. doi: 10.31830/2348-7542.2018.0001.39

12. Marek M, Zouhar M, Rysanek P, Havranek P. Analysis of ITS sequences of nuclear rDNA and development of a PCR-based assay for the rapid identification of the stem nematode Ditylenchus dipsaci (Nematoda: Anguinidae) in plant tissues. Helminthologia. 2005; 42(2):49—56.

13. Esquibet M, Grenier E, Plantard O, Andaloussi FA, Caubel G. DNA polymorphism in the stem nematode Ditylenchus dipsaci: development of diagnostic markers for normal and giant races. Genome. 2003; 46(6):1077-1083. doi: 10.1139/g03-072

14. Subbotin SA, Madani M, Krall E, Sturhan D, Moens M. Molecular diagnostics, taxonomy, and phylogeny of the stem nematode Ditylenchus dipsaci species complex based on the sequences of the internal transcribed spacer-rDNA. Phytopathology. 2005; 95(11):1308-1315. doi: 10.1094/PHYTO-95-1308

15. Naserzadeh Y, Mahmoudi N. Chelating effect of black tea extract compared to citric acid in the process of the oxidation of sunflower, canola, olive, and tallow oils. International Journal of Agricultural and Biosystems Engineering. 2018; 12 (5): 5. doi: 10.13140/RG.2.2.12552.26887

16. Fand BB, Amala U, Yadav D, Rathi G, Mhaske SH, Upadhyay A, et al. Bacterial volatiles from mealybug honeydew exhibit kairomonal activity toward solitary endoparasitoid Anagyrus dactylopii. Journal of Pest Science. 2019:1-12. doi: 10.1007/s10340-019-01150-4

17. OEPP/EPPO. PM 7/87(2) Ditylenchus destructor and Ditylenchus dipsaci. Bulletin OEPP/ EPPO Bulletin. 2017; 47(3):401-419. doi: 10.1111/epp.12433

18. Naserzadeh Y, Mahmoudi N, Pakina E. Antipathogenic effects of emulsion and nanoemulsion of cinnamon essential oil against Rhizopus rot and grey mold on strawberry fruits. Foods and Raw materials. 2019; 7(1):210-216. doi: 10.21603/2308-4057-2019-1-210-216

\begin{abstract}
About authors:
Mahmoudi Niloufar - PhD candidate, Department of Agro-Biotechnology, Agrarian and Technological Institute, Peoples' Friendship University of Russia (RUDN University), 8, Miklukho-Maklaya st., Moscow, 117198, Russian Federation; Researcher, Russian Plant Quarantine Center (VNIIKR), 32, Pogranichnaya st., vill. Bykovo, Ramensky district, Moscow region, 140150, Russian Federation; e-mail: niloofarmahmoodi@ymail.com
\end{abstract}

Naserzadeh Yousef - PhD candidate, Department of Agro-Biotechnology, Agrarian and Technological Institute, Peoples' Friendship University of Russia (RUDN University), 8, Miklukho-Maklaya st., Moscow, 117198, Russian Federation; Researcher, Russian Plant Quarantine Center (VNIIKR), 32, Pogranichnaya st., vill. Bykovo, Ramensky district, Moscow region, 140150, Russian Federation; e-mail: unaserzadeh@gmail.com

Pakina Elena - PhD, Associate Professor, Department of Agro-Biotechnology, Agrarian and Technological Institute, Peoples' Friendship University of Russia (RUDN University), 8, MiklukhoMaklaya st., Moscow, 117198, Russian Federation; e-mail: e-pakina@yandex.ru

Limantceva Liudmila - PhD, Senior scientist, Plant Quarantine Center (VNIIKR), 32, Pogranichnaya st., vill. Bykovo, Ramensky district, Moscow region, 140150, Russian Federation; e-mail: Limantseva.ludmila@vniikr.ru

Nejad Davoud Kartuli - Assistant Professor of Forestry, Faculty of Desert Studies, Semnan University, Mowlawi Boulevard, Motahari Square, 35196-45399, Semnan, Iran; e-mail: Kartooli58@gmail.com 


\title{
Молекулярная идентификация нематоды Ditylenchus destructor методом полимеразной цепной реакции с использованием специфических праймеров в Московской области
}

\author{
Н. Махмуди ${ }^{1,2 *}$, Ю. Насерзаде ${ }^{1,2}$, Е.Н. Пакина ${ }^{1}$, \\ Л.А. Лиманцева ${ }^{2}$, Д.К. Неджад ${ }^{3}$ \\ ${ }^{1}$ Российский университет дружбы народов, Москва, Российская Федераџия \\ ${ }^{2}$ Всероссийский центр карантина растений (ВНИИКР), \\ Московская область, Российская Федерация \\ ${ }^{3}$ Университет Семнан, Семнан, Иран \\ *niloofarmahmoodi@ymail.com
}

\begin{abstract}
Аннотация. Картофель Solanum tuberosum L. — одна из наиболее важных продовольственных и технических культур, a Ditylenchus destructor является патогенной нематодой картофеля и числится в качестве карантинного вредного организма во многих странах и регионах. Поэтому был оптимизирован протокол полимеразной цепной реакции (ПЦР), который надежно и быстро идентифицирует деструктор Ditylenchus. Видоспецифичный внутренний транскрибируемый спейсер (ITS) использовали в качестве праймера гена рибосомальной ДНК деструктора Ditylenchus. Некоторые популяции этого вида в Московской области были исследованы с помощью видоспецифического праймера ПЦР. Новая последовательность из ITS-pPHК была депонирована в GenBank под инвентарным номером MN122076. Современная молекулярная техника лучше подходит для различения видов нематод, поскольку она практична, быстра и точна.
\end{abstract}

Ключевые слова: картофель, диагностика, Ditylenchus destructor, видоспецифический праймер, полимеразная цепная реакция, нематода, внутренний транскрибируемый спейсер, ITS

\section{БЛАГОДАРНОСТИ}

Исследование проведено при финансовой поддержке Программы РУДН «5-100».

\section{История статьи:}

Поступила в редакцию: 5 сентября 2019 г. Принята к публикации: 29 ноября 2019 г.

\section{Для цитирования:}

Mahmoudi N, Naserzadeh Y, Pakina E.N., Limantceva L.A., Nejad DK. Molecular identification of Ditylenchus destructor nematode with PCR Species-Specific primers in the Moscow region // Вестник Российского университета дружбы народов. Серия: Агрономия и животноводство. 2019. T. 14. № 4. C. 430 — 436. doi: 10.22363/2312-797X-2019-14-4-430-436

\section{Об авторах:}

Махмуди Нилоуфар - аспирант, агробиотехнологический департамент, Аграрно-технологический институт, Российский университет дружбы народов, Российская Федерация, 117198, Москва, ул. Миклухо-Маклая, 8; научный сотрудник Всероссийского центра карантина растений, Российская Федерация, Московская область, 140150, Раменский район, п. Быково, ул. Пограничная, д. 32; e-mail: niloofarmahmoodi@ymail.com 
Насерзаде Юсеф - аспирант, агробиотехнологический департамент, Аграрно-технологический институт, Российский университет дружбы народов, Российская Федерация, 117198, Москва, ул. Миклухо-Маклая, 8; научный сотрудник Всероссийского центра карантина растений, Российская Федерация, Московская область, 140150, Раменский район, п. Быково, ул. Пограничная, д. 32; e-mail: unaserzadeh@gmail.com

Пакина Елена Николаевна - кандидат биологических наук, доцент, агробиотехнологический департамент, Аграрно-технологический институт, Российский университет дружбы народов, Российская Федерация, 117198, Москва, ул. Миклухо-Маклая, д. 8; e-mail: e-pakina@yandex.ru

Лиманцева Людмила Алексеевна - кандидат биологических наук, старший научный сотрудник, Всероссийский центр карантина растений (ВНИИКР), Российская Федерация, Московская область, 140150, Раменский район, п. Быково, ул. Пограничная, д. 32; e-mail: Limantseva.ludmila@vniikr.ru

Неджад Давуд Картули - доцент кафедры лесоводства, факультет исследований пустынь, Университет Семнан, Иран, 35196-45399, Семнан, площадь Мотахари, бульвар Молави; e-mail: Kartooli58@gmail.com 